\title{
Brüchige „Heimatfront”. Mobilisierung und Überleben im Hinterland im Ersten Weltkrieg
}

\begin{abstract}
Die vorgestellte Gemeinschaft der „Heimatfront“ im Ersten Weltkrieg verlangte von den Angehörigen der Zivilgesellschaft, vor allem Frauen und Kindern, ein Höchstmaß an „Opferwilligkeit“, um deren (im-)materielle Ressourcen für das Kriegsprojekt zu mobilisieren. Wie jedoch die Felder der „Ernährungs-“ und der „Schulfront“ zeigen, misslang der Aufbau einer imperialen Opfergemeinschaft letztendlich - nicht nur an den Rändern des Reiches, sondern auch im Zentrum, der Reichshauptstadt Wien und dem niederösterreichischen Kernland. Dieser Gemeinschaftsentwurf scheiterte weniger an den äußeren Kriegsgegnern, sondern vielmehr an inneren Spannungen: Viktimisierte Gruppen der Kriegsgesellschaft mobilisierten Gegenbewegungen und entzogen den zivilen und militärischen Autoritäten die Legitimität.
\end{abstract}

The Fragile "Home Front". Mobilisation and Livelihood in the Hinterland during the First World War. The imagined community of the "Home Front" in the First World War demanded a high degree of "willingness to make sacrifices" from members of civil society, above all women and children, in order to mobilise their (im-) material resources for the war effort. However, as revealed by the fields of the "food front" and the "school front", the creation of an imperial community of sacrifice ultimately failed - not only on the empire's periphery, but also in the centre: the imperial capital of Vienna and the Lower Austrian heartland. This attempt at community-building failed due to internal tensions rather than external opponents of the war: victimised groups of wartime society mobilised counter-movements, thereby depriving the civil and military authorities of their legitimacy.

Keywords: home front, food, school, victimisation, everyday life

doi.org/10.52035/noil.2021.19jh02.18

Veröffentlicht nach externer Begutachtung (doppelblind) / published after external peer review (double blind) 